\title{
Impact of economic and financial factors on tax revenue: Evidence from the Middle East countries
}

\author{
Muhammad Farhan Basheer ${ }^{a^{*}}$, Aref Abdullah Ahmad ${ }^{b}$ and Saira Ghulam Hassan
}

${ }^{a}$ School of Economics Banking and Finance, University of Utara Malaysia

${ }^{b}$ Management and Science University, Malaysia

${ }^{c}$ School of Economics Banking and Finance, University of Utara Malaysia

CHRONICLE

Article history:

Received March 3, 2018

Received in revised format June 112018

Accepted August 122018

Available online

August 122018

Keywords:

Middle East Countries

Bahrain

Oman

Economic Factors

Financial Factors

Tax revenue and GDP growth

\begin{abstract}
A B S T R A C T
This paper examines the impact of economic and financial factors on tax revenue of Bahrain and Oman from 1990 to 2010. For this purpose, panel regression analysis is performed by considering economic and financial factors including growth domestic product (GDP), Deposit Interest Rate, Lending Interest Rate, Interest Rate Spread, Real Interest Rate, Bank Capital to Asset Ratio, Bank nonperforming loans to total gross loans, Risk premium on lending, Foreign direct investment net inflow and Cash surplus deficit. A conceptual model is developed for this purpose and the key findings are explained. The outcomes of the study explain that there was a significant relationship between Tax revenue and both economic and financial factors i.e. GDP growth, Bank capital to asset ratio, the Risk premium on lending, Foreign direct investment net inflow and Cash surplus/deficit over the period of study. The findings of the study are very much useful for the policymakers to consider which factors are affecting the tax revenues and in which direction. However, the findings of the study can be more meaningful with the addition of more economic and financial factors as well. Besides, the consideration of other Asian states will provide more evidence for the generalization of the findings. Meanwhile, this study will be a policy note on on-going tax reforms in selected Middle East countries and will be helpful for policymakers and researchers in conceptualizing the tax revenue model for them.
\end{abstract}

\section{Introduction}

For both developed and developing economies, tax revenues are the major sources for the economic sustainability and growth (Chemingui \& Roe, 2008). For the central government, tax revenues are the main source of revenues, even for the aid-dependent and low-income countries. The aim of taxation is to meet the public needs and government of any country is under intense need of tax revenues for the economic welfare and justice in the society (Bofah, 2003). In many poor countries, lower tax rates have stopped them to get the ambitious development programs. It is considered as the mega revenue sources since the tax is collected from companies, investors and from citizens to generate the economy. As per the theory of tax competition, through the occurrence of globalization, the government will reduce the

* Corresponding author.

E-mail address: Khwaja.farhan7@gmail.com (M. F. Basheer) 
taxes on the mobile assets. Such policy will be implemented due to rising in the economic growth of the country as the changes in tax rate provide various impacts on the economy. In the study of Bretschger (2010) and Devereux and Maffini (2007), they found an inverse impact of corporate taxes on the trade openness and even on total revenues of the taxes of 12 OECD states. They also provided the argument that when the tax rate is comparatively low it can provide the opportunity for the capital inflow in the country. In these works, four objectives of taxation have been found. These are the revenue collection for the government, redistribution of the amount from rich to poor, reprising (levied on the harmful products like tobacco) and finally the accountability in front of public by the government (Aamir et al., 2011). Various factors are playing a vital role in determining the tax rates in the economy. These are from both economic and financial sector.

From the last three decades, many countries located in the Middle East Countries have been the legal and safe tax heavens. However, the recent economic turmoil which emerged because of highly volatile oil prices in the global market has forced these countries to shift their focus on the non-oil-based revenues and started imposing direct and indirect taxes. KSA and UAE have imposed 5 percent direct tax. The focus of this study is also on two countries of Oman and Bahrain. In Oman, the tax revenue reached to $\$ 630$ million in 2010 from $\$ 124$ million in 2000 . In the same time span, the tax to GDP ratio increased from 1.66 percent to 2.54 percent per year. On taking larger time span the tax to GDP ratio was decreased from 9.36 percent in 1990 to 2.54 percent in 2010. Similarly, the tax revenue of Bahrain increased from $\$ 82$ million in 1990 to $\$ 113$ million in 2010. Whereas the tax revenue to GDP ratio was decreased from 5.19 percent in 1990 to 1.18 in 2010 as shown in Fig. 1.

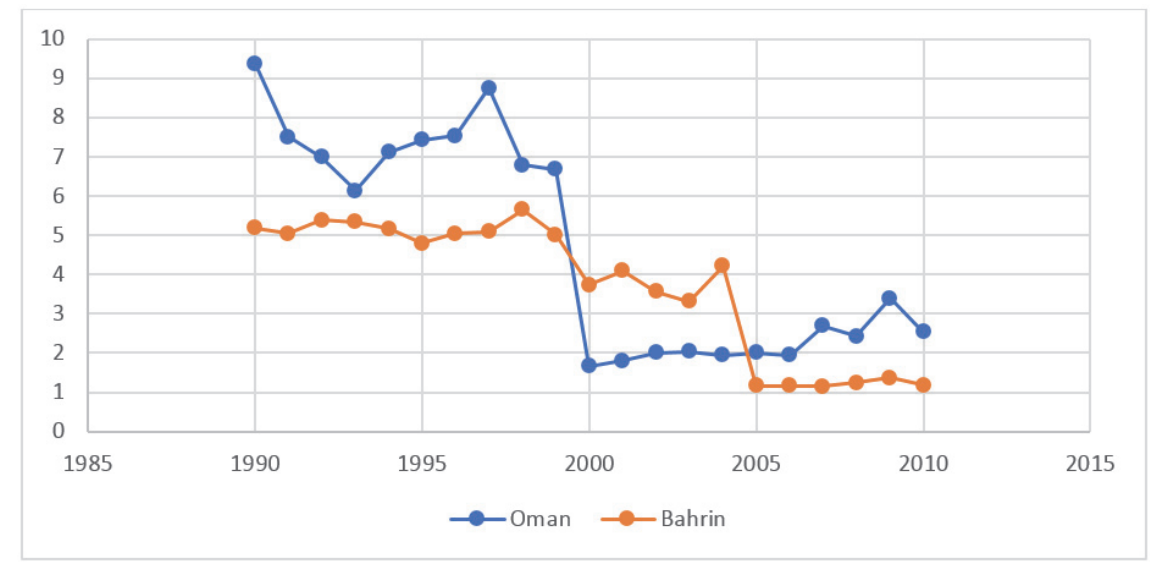

Fig. 1. Tax to GDP ratio of Bahrain and Oman from 1990 to 2010

Source: International Monetary Fund, Government Finance Statistics Yearbook, and data files

The core purpose of this study is to examine the relationship between tax revenue and both economic and financial sector variables of Bahrain and Oman. Variables that are considered in this study are tax revenue \% of GDP (dependent variable), GDP growth, deposit interest rate, lending interest rate, interest rate spread, real interest rate, bank capital to asset ratio, bank nonperforming loans to total gross loans, risk premium on lending, foreign direct investment net inflows, cash surplus/deficit, which are considered as the independent variables. As per the report of Countries Cooperation Council GCC in the region, major sources of tax revenues for the Middle East Countries are: personal income, corporate income, goods \& services, trade property, etc. Besides GCC, governments have put significant efforts to increase the non-oil tax revenues, as it is low as per the international standards. Clustered column chart shown in Fig 2 represents the total, non-oil, tax and oil revenues for the Middle East Countries 


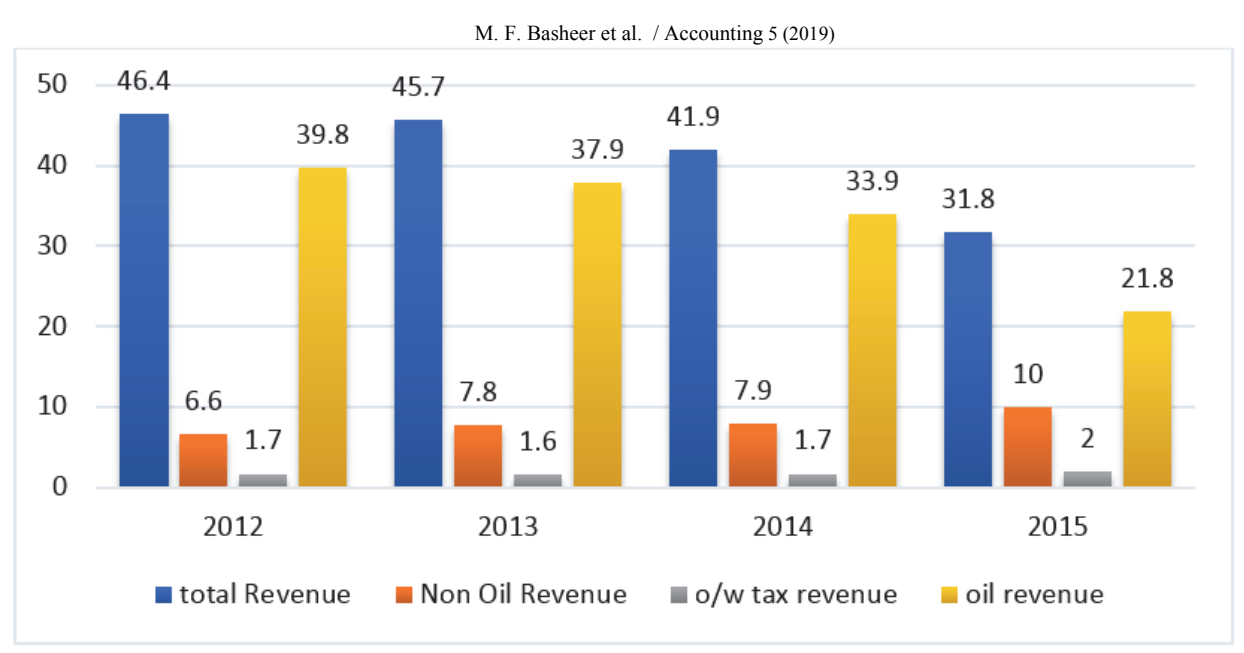

Fig. 2. Distribution of revenue in middle east countries

Sources: IMF WEO; and staff estimates

From the above data, it is clear that the total revenue and the revenue from oil and gas sector is decreasing during from 2012 to 2015. Considering these factors, the Middle East Countries are on way to impose a new set of direct and indirect taxes. Therefore, the current study will be helpful for the policymakers and researchers in assessing the impact of recent reforms on tax policies on country growth. Meanwhile, it helps them in understanding the link between different macroeconomic factors which play a critical role in determining tax policy of any country.

\section{Literature review}

Tax revenues and structure are significantly linked with the economic growth. During the last decade, many people have studied the association between the taxation and growth of the economy (Arnold, 2008; Arnold et al., 2011; Johansson et al., 2008:Addison \& Levin, 2011; Al-Faris, 2002). They provided some link between the taxes and economic growth and described significant evidence relatively to those with the focus on the level of taxation only. The empirical findings are considered as sufficient and reliable evidence for the relationship between taxes and economic growth. The relationship between GDP and tax revenues has become under great focus in the field of economics. Various economists believed that higher tax rates are not good for the economic growth and have used tax multiplier to analyze the negative association between GDP and Tax revenues. GDP is normally used as an indicator of economic health and to gauge the standard of living in the country. In the early 90s, many scientists examined the growth rate of GDP per capita with the average tax rate in 24 OECD countries from 1960 to 1989 (Plosser, 1992; Gale \& Samwick, 2014; Hakim \& Bujang, 2012). However, some have studied the dynamic effect of taxes on the overall economy through mathematical models. Some researchers used the vector auto regressor VAR model, based on the Romanian economy from 1999-2010 (Yi \& Suyono, 2014; McBride, 2012).

The effect of the foreign direct investment (FDI) on the progress of the host country through tax revenues has also been under researchers' attention. FDI has been widely accepted as one of a beneficial factor for the host country because it provides new growth opportunities. Based on the theoretical model, some studies explained the impact of FDI on the government revenue (taxes) (Nguyen et al., 2013; Stoilova \& Patonov, 2013). They explained that the impact of FDI on taxes could depend on the level of competition in the market and technological spillover. Besides, the degree of contribution by FDI in tax revenues also depends on the creation of demand and transfer of technological cost (Nguyen et al., 2013). However, the reciprocal association between FDI and tax revenues was also presented in the previous literature. For example, Hartman (1985) studied the relationship between the tax revenues 
and FDI from the perspective of the American economy. His findings provided the argument that FDI in the US had been strongly affected by the change in the domestic tax policy by the Government.

The link between taxes and a capital ratio of the firms like banks was also under discussion in existing literature. In a recent study, Faccio and Xu (2015) used the quasi-experimental setting for the shifting in corporate and personal taxes in OECD countries from 1981 to 2009. Their findings provided the fact that taxes rates and capital structure and related decisions had significant linkage. Besides, the study of Schepens (2016) is among the significant contribution to study the relationship between taxes and a capital ratio of the banking firms. Their study exploits the exogenous variation in the treatment of taxes for the mixture of debt and equity ratio of Belgium banking economy. Their findings are consistent with the supposition that both low and high capitalized banking firms are reacting towards the tax legislation.in addition, overall findings confirm that reduction in tax discrimination could be an innovative policy for the banking regulations.

Besides, some financial sector indicators like non-performing loans have also shown a significant impact on the tax revenues of the country (Noeth \& Sengupta, 2012). Poor economic performance of the country leads to the increasing level of nonperforming loans (NLPs) in the economy and finally lowers the tax revenues as well. This is due to the reason that NPLs shrink the balance sheet size of the banking firms which in returns affect the economic growth (Bernanke \& Gertler, 1995). In some of the extreme cases, non-performing loans end with the failure of the bank and large bailouts with the lower tax revenue which finally put extreme stress on the public debt (Reinhart \& Rogoff, 2009). Besides the relationship of deposit interest rate, real interest rate and lending interest with the tax revenues were not explored and very limited attention has been paid on this association (Artavanis et al., 2015, 2016; Johannesen, 2014; Javed \& Basheer, 2017). So, in the present study, all three indicators of interest rate (deposit interest rate, lending interest rate, and real interest rate) are selected to explore their links with the tax revenues in the middle east countries. Besides two economic and financial sector indicators like cash surplus/deficit and the risk premium on lending are also among the major explanatory variables of the study.

Fig. 1 shows the economic and financial factors, which are used in the proposed study. All these factors are considered as the major explanatory variables for defining the Tax Revenue.
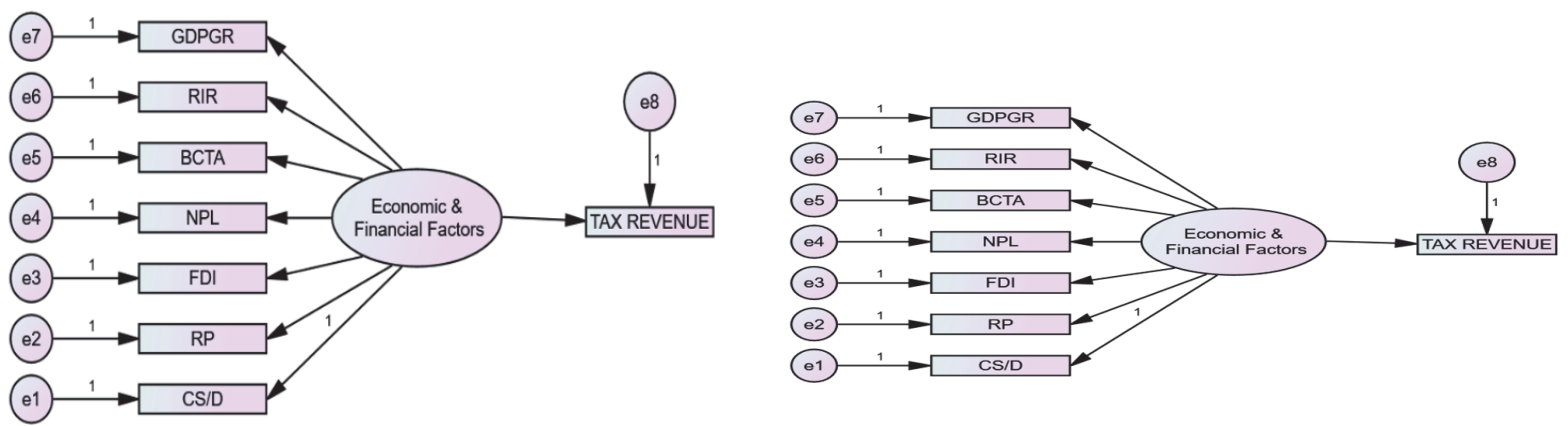

Fig. 1. The proposed study

\section{Hypothesis}

$\mathbf{H}_{\mathbf{0}}$ : Economic and Financial factors have no impact on Tax Revenue.

$\mathbf{H}_{1}$ : Economic and Financial factors influence on Tax Revenue.

Data for all the selected variables are collected from the official website of World Bank; known as World Development Indicator WDI. The time duration of the study is from the year 1990 to 2014 for Oman and Bahrain. The details of the variables used in the current study is given in Table 1. 
Table 1

Details of variables

\begin{tabular}{ll}
\hline Variables & \\
\hline Tax Revenue (DV) & TR \\
GDP Growth & GDPGR \\
Deposit Interest Rate & DIR \\
Lending Interest Rate & LIR \\
Interest Rate Spread & IRS \\
Real Interest Rate & RIR \\
Bank Capital to Asset Ratio & BCTA \\
Bank nonperforming loans to total gross loans & BNL \\
The risk premium on lending & RP \\
Foreign direct investment, net inflows & FDI \\
Cash surplus/deficit & CS/D \\
\hline
\end{tabular}

\section{Econometric Model}

To achieve the objective of the study we have employed panel date techniques, which are most suitable in our case (Basheer, 2014). For the proposed study, Tax revenue (Y) which is measured as the ratio of tax revenue to GDP is selected as the dependent variable while GDP Growth rate (GDPGR), Deposit Interest Rate (DIR), Lending Interest Rate (LIR), Interest Rate Spread (IRS), Real Interest Rate (RIR), Bank Capital to Asset Ratio (BCAR), Bank nonperforming loans to total gross loans (NPLS), Risk premium on lending (RP), Foreign direct investment FDI, in terms of net inflows and Cash surplus/deficit are selected as major explanatory variables from both economic and financial sector. Time of the data set is from 1999 to 2014 . The proposed study is given in Eq. (1) and Table 2 presents some basic statistics.

$$
Y_{i t}=b_{0}+b_{1} G D P G R_{i t}+b_{2} D I R_{i t}+b_{3} L I R_{i t}+b_{4} I R D S_{i t}+b_{5} R I R_{i t}+b_{6} B C A R_{i t}+b_{7} N P L S_{i t}+b_{8} R P_{i t}+b_{9} F D I_{i t}+\varepsilon_{i t} \text {. }
$$

\section{Table 2}

Descriptive statistics

\begin{tabular}{lccc}
\hline Variables & Obs. & Mean & Std. Dev. \\
\hline TR & 80 & 2.39 & 5.54 \\
GDPGR & 80 & 5.67 & 9.11 \\
DIR & 80 & 3.33 & 2.42 \\
LIR & 80 & 7.18 & 4.18 \\
IRS & 80 & 3.93 & 2.33 \\
RIR & 80 & 0.79 & 11.78 \\
BCTA & 80 & 5.12 & 6.18 \\
NPLs & 80 & 3.15 & 3.96 \\
RP & 80 & 2.13 & 2.75 \\
FDI & 80 & $1.20 \mathrm{E}+09$ & $1.53 \mathrm{E}+09$ \\
CS/D & 80 & 3.42 & 7.66 \\
\hline
\end{tabular}

Table 2 shows the results of the descriptive statistics of the study. The total number of observations for all the variables is 80 . Table 3 describes the correlation matrix between all the variables selected for the present study analysis. It can be seen from table that GDP growth and Tax Revenue had a significant correlation of 0.3673 . Similarly, Deposit Interest Rate has a significant correlation with GDP growth with a coefficient value of 0.2664 . Lending Interest Rate had a significant correlation with GDP growth and Deposit Interest Rate i.e. $0.0154 * *$ and $0.0000^{* * *}$ with the coefficient values of 0.2702 and 0.8285 . Interest Rate Spread had a significant correlation with GDP growth with the value of $0.0985^{*}$, also Interest Rate Spread maintained a significant correlation with Deposit Interest Rate and Lending Interest Rate with the values of $0.0000^{* * *}$ and $0.0000^{* * *}$. There was no significant correlation value in Real Interest Rate and Bank Capital to Asset Ratio with other variables. Bank nonperforming loans to total gross loans had a significant correlation with GDP growth and Bank Capital to Asset Ratio with the value of $0.0572 *$ and $0.0000^{* * *}$ having the coefficient value of -0.2136 and 0.5721 . The risk premium on lending had a significant correlation with Tax revenue, Lending Interest Rate and Interest 
Rate Spread having the value of $0.0120 * *, 0.0003 * * *$ and $0.0000 * * *$ with the coefficient values of $0.2796,0.3973$ and 0.5834 . Foreign direct investment net inflow had a significant correlation with Tax revenue, GDP growth and Bank nonperforming loans to total gross loans with the value of $0.0000^{* * *}$, $0.0154 * *$ and $0.0239 * *$ respectively. Cash surplus deficit had a significant correlation with Tax revenue, Bank Capital to Asset Ratio, Bank nonperforming loans to total gross loans and Foreign direct investment net inflow having the value of $0.0074 * *, 0.0112 * *, 0.0830 *$ and $0.0410^{* *}$ respectively. To check the overall level of correlation among the selected variables of the study, Variance Inflation Factor VIF is calculated which explains is there any problem of multicollinearity in the data set or not.

Table 3

Correlation matrix

\begin{tabular}{|c|c|c|c|c|c|c|c|c|c|c|c|}
\hline & TR & GDPGR & DIR & LIR & IRS & RIR & BCAR & BNPL & RP & FDI & CSD \\
\hline TR & 1 & & & & & & & & & & \\
\hline GDPGR & $\begin{array}{l}0.367 \\
0.0008 * * *\end{array}$ & 1 & & & & & & & & & \\
\hline DIR & $\begin{array}{l}0.068 \\
0.544\end{array}$ & $\begin{array}{l}0.266 \\
0.016^{* *}\end{array}$ & 1 & & & & & & & & \\
\hline LIR & $\begin{array}{l}0.003 \\
0.974\end{array}$ & $\begin{array}{l}0.27 \\
0.015 * *\end{array}$ & $\begin{array}{l}0.828 \\
0.000 * * *\end{array}$ & 1 & & & & & & & \\
\hline IRS & $\begin{array}{l}-0.08 \\
0.477\end{array}$ & $\begin{array}{l}0.186 \\
0.098^{*}\end{array}$ & $\begin{array}{l}0.49 \\
0.000 * * *\end{array}$ & $\begin{array}{l}0.872 \\
0.000^{* * *}\end{array}$ & 1 & & & & & & \\
\hline RIR & $\begin{array}{l}-0.014 \\
0.897\end{array}$ & $\begin{array}{l}-0.114 \\
0.314\end{array}$ & $\begin{array}{l}0.0004 \\
0.997\end{array}$ & $\begin{array}{l}0.062 \\
0.583\end{array}$ & $\begin{array}{l}0.1084 \\
0.3384\end{array}$ & 1 & & & & & \\
\hline BCAR & $\begin{array}{l}-0.172 \\
0.127\end{array}$ & $\begin{array}{l}-0.156 \\
0.164\end{array}$ & $\begin{array}{l}-0.142 \\
0.208\end{array}$ & $\begin{array}{l}-0.111 \\
0.325\end{array}$ & $\begin{array}{l}-0.0812 \\
0.4742\end{array}$ & $\begin{array}{l}-0.039 \\
0.73\end{array}$ & 1 & & & & \\
\hline BNPL & $\begin{array}{l}-0.126 \\
0.265\end{array}$ & $\begin{array}{l}-0.213 \\
0.057^{*}\end{array}$ & $\begin{array}{l}0.044 \\
0.692\end{array}$ & $\begin{array}{l}0.015 \\
0.892\end{array}$ & $\begin{array}{l}-0.0462 \\
0.6838\end{array}$ & $\begin{array}{l}-0.005 \\
0.958\end{array}$ & $\begin{array}{l}0.572 \\
0.000^{* * *}\end{array}$ & 1 & & & \\
\hline $\mathbf{R P}$ & $\begin{array}{l}-0.279 \\
0.012 * *\end{array}$ & $\begin{array}{l}0.163 \\
0.146\end{array}$ & $\begin{array}{l}0.103 \\
0.363\end{array}$ & $\begin{array}{l}0.397 \\
0.0003 * * *\end{array}$ & $\begin{array}{l}0.5834 \\
0.000^{* * *}\end{array}$ & $\begin{array}{l}0.1552 \\
0.169\end{array}$ & $\begin{array}{l}-0.075 \\
0.503\end{array}$ & $\begin{array}{l}-0.028 \\
0.802\end{array}$ & 1 & & \\
\hline FDI & $\begin{array}{l}0.533 \\
0.000^{* * *}\end{array}$ & $\begin{array}{l}0.27 \\
0.015 * *\end{array}$ & $\begin{array}{l}0.113 \\
0.314\end{array}$ & $\begin{array}{l}0.11 \\
0.33\end{array}$ & $\begin{array}{l}0.0529 \\
0.6411\end{array}$ & $\begin{array}{l}0.156 \\
0.166\end{array}$ & $\begin{array}{l}-0.12 \\
0.287\end{array}$ & $\begin{array}{l}-0.252 \\
.023 * *\end{array}$ & $\begin{array}{l}-0.153 \\
0.1755\end{array}$ & 1 & \\
\hline CSD & $\begin{array}{l}0.297 \\
0.007 * * *\end{array}$ & $\begin{array}{l}0.157 \\
0.164\end{array}$ & $\begin{array}{l}-0.011 \\
0.921\end{array}$ & $\begin{array}{l}-0.071 \\
0.53\end{array}$ & $\begin{array}{l}-0.1345 \\
0.2342\end{array}$ & $\begin{array}{l}-0.097 \\
0.39\end{array}$ & $\begin{array}{l}0.282 \\
0.011^{* *}\end{array}$ & $\begin{array}{l}0.195 \\
0.083^{*}\end{array}$ & $\begin{array}{l}0.001 \\
0.99\end{array}$ & $\begin{array}{l}0.229 \\
0.041 * *\end{array}$ & 1 \\
\hline
\end{tabular}

Table 4

VIF outcomes

\begin{tabular}{lll}
\hline Variable & VIF & $1 / \mathrm{VIF}$ \\
\hline LIR & 39.07 & 0.025 \\
IRS & 18.13 & 0.055 \\
DIR & 11.78 & 0.084 \\
RP & 1.95 & 0.512 \\
BNL & 1.74 & 0.575 \\
BCTA & 1.67 & 0.600 \\
FDI & 1.44 & 0.696 \\
CSD & 1.34 & 0.747 \\
GDPGR & 1.32 & 0.755 \\
RIR & 1.14 & 0.880 \\
MEAN VIF & 7.96 & \\
\hline
\end{tabular}

Table 4 explains the actual outcomes of VIF for the individual factors as well as the mean VIF. Here the VIF for LIR, IRS, DIR is greater than 10, which is stated criteria to explain that there is no problem of high correlation in the data set. Therefore, finally, all these three indicators are dropped, and new regression equation is finalized which is as below.

$$
Y_{i t}=b_{0}+b_{1} G D P G R_{i t}+b_{2} R I R_{i t}+b_{3} B C T A_{i t}+b_{4} N P L S_{i t}+b_{5} R P_{i t}+b_{6} F D I_{i t}+\varepsilon_{i t} \text {, }
$$

where these explanatory factors have no problem for the high correlation as individual VIF is below 5. So finally, we can go for the Panel regression models which are Least Square Dummy variable model, Fixed effect model FEM, Random Effect Model REM and finally Pooled regression model PRM. Table 5 shows the outcomes of panel data analysis for a dependent variable which is (tax revenue). The results in the above table demonstrate the outcomes for LSDVM, FEM, REM, and PRM. The results of LSDVM and FEM analysis are the same, so we interpret them collectively. 
Table 5

Regression outcomes

\begin{tabular}{|c|c|c|c|c|c|c|c|c|}
\hline \multirow[b]{2}{*}{ TR } & \multicolumn{2}{|c|}{ LSDVM } & \multicolumn{2}{|c|}{ FEM } & \multicolumn{2}{|c|}{ REM } & \multicolumn{2}{|c|}{ PRM } \\
\hline & Coef. & $\mathrm{P}>\mathrm{t}$ & Coef. & $\mathrm{P}>\mathrm{T}$ & Coef. & $\mathrm{P}>\mathrm{T}$ & Coef. & $\mathrm{P}>\mathrm{T}$ \\
\hline GDPGR & 0.077 & 0.205 & 0.077 & 0.205 & 0.176 & $0.004 * * *$ & 0.176 & $0.005 * * *$ \\
\hline RIR & 0.009 & 0.816 & 0.009 & 0.816 & 0.008 & 0.845 & 0.008 & 0.845 \\
\hline BCTA & -0.032 & 0.808 & -0.032 & 0.808 & -0.228 & $0.024 * *$ & -0.228 & $0.027 * *$ \\
\hline NPL & 0.198 & 0.245 & 0.198 & .0 .245 & 0.177 & 0.271 & 0.177 & 0.275 \\
\hline $\mathrm{RP}$ & -0.238 & 0.426 & -0.238 & 0.426 & -0.712 & $0.004 * * *$ & -0.712 & $0.005 * * *$ \\
\hline FDI & $9.58 \mathrm{e}-10$ & $0.009 * * *$ & $9.58 \mathrm{e}-10$ & $0.009 * * *$ & $1.28 \mathrm{e}-09$ & $0.001 * * *$ & $1.28 \mathrm{e}-09$ & $0.001 * * *$ \\
\hline $\mathrm{CS} / \mathrm{D}$ & 0.243 & $0.007 * * *$ & 0.243 & $0.007 * * *$ & 0.171 & $0.019 * *$ & 0.171 & $0.022 * *$ \\
\hline cons & 0.774 & 0.557 & 0.774 & 0.557 & 1.073 & 0.384 & 1.073 & 0.387 \\
\hline & $\mathrm{F}(11,68)$ & $=8.66$ & $\mathrm{~F}(11,68)$ & $=8.66$ & within $=$ & 456 & $\mathrm{~F}(7,72)=$ & $8.87 * * *$ \\
\hline & Prob $>F=$ & $=0.0000$ & Prob $>F=$ & $=0.0000$ & between $=$ & 7411 & Prob $>F=$ & .0000 \\
\hline Model & R-squared = & $=0.5834$ & R-squared = & $=0.5834$ & & & R-squared & 0.4630 \\
\hline Summary & $\operatorname{Adj} \mathrm{R} 2=$ & 0.5160 & $\operatorname{Adj} \mathrm{R} 2=$ & 0.5160 & overall $=$ & 628 & $\operatorname{Adj} \mathrm{R} 2=$ & 0.4108 \\
\hline
\end{tabular}

The only difference between LSDVM and FEM is that LSDVM not just controls the individual heterogeneous effect of the firms and years but show them also. For the simplicity of analysis, no such fixed effects for individual states or years are presented. The coefficient values of foreign direct investment net inflow and Cash Surplus deficit are 9.58e-10 and 0.243, which are significant at $0.9 \%$ and $0.5 \%$ respectively. Besides the value of coefficients under all the 4 stated models is significant for FDI and CS/D ratio but the value of RP is significant under both REM and PRM. The findings of the study also explain that GDGR had a positive and significant impact on tax revenues under REM and PRM regression techniques. All the regression models are significant and good for the final recommendations as f-statistics is significant at $5 \%$. In the final step, the comparison between fixed and random effect is made through Hausman test and following hypotheses are developed. The implementation of Hausman test yields a Chi-Square value of $111.95(0.0000 * * *)$, which means we accept Fixed Effect and reject the Random Effect and finally conclude that fixed effect findings are good for the decision making. The value of $\mathrm{R}^{2}$ for the fixed effect model $58 \%$, which explains total variation in DV; tax revenues by all the explanatory variables of the study.

\section{Conclusion}

From the above discussion, it is quite clear that discussing the Tax Revenue is not an independent decision. It is affected by both economic and financial factors of the countries. The key factors which have a significant contribution both from economic and financial factors are GDP growth, Bank capital to asset ratio, Risk premium on lending, Foreign direct investment net inflow and Cash surplus deficit. From the results, it is found that the economic variables such as GDP growth, Foreign direct investment net inflow and Cash surplus deficit Tax Revenue had a greater impact on Tax Revenue than those on financial variables. Although the financial variables like Bank capital to asset ratio and the Risk premium on lending also had a significant impact on. Besides some future recommendations is the implication of present study on all the OECD countries by expanding the sample size. Thus, we can argue that the economic growth has a significant impact on tax policy of Oman and Bahrain. The current study will be helpful for the policymakers and researchers for assessing the impact of recent reforms on tax policies on country growth. Meanwhile, it helps them in understanding the link between different macroeconomic factors, which play a critical role in determining tax policy of any country.

\section{References}

Aamir, M., Qayyum, A., Nasir, A., Hussain, S., Khan, K. I., \& Butt, S. (2011). Determinants of tax revenue: A comparative study of direct taxes and indirect taxes of Pakistan and India. International Journal of Business and Social Science, 2(19).

Addison, T., \& Levin, J. (2011). The determinants of tax revenue in sub-Saharan Africa. Journal of International Development. 
Al-Faris, A. F. (2002). Public expenditure and economic growth in the Gulf Cooperation Council countries. Applied Economics, 34(9), 1187-1193.

Arnold, J. (2008). Do Tax Structures Affect Aggregate Economic Growth?

Arnold, J. M., Brys, B., Heady, C., Johansson, Å., Schwellnus, C., \& Vartia, L. (2011). Tax policy for economic recovery and growth. The Economic Journal, 121(550).

Artavanis, N., Morse, A., \& Tsoutsoura, M. (2015). Tax evasion across industries: soft credit evidence from Greece: National Bureau of Economic Research.

Artavanis, N., Morse, A., \& Tsoutsoura, M. (2016). Measuring income tax evasion using bank credit: Evidence from Greece. The Quarterly Journal of Economics, 131(2), 739-798.

Basheer, M. F. (2014). Impact of Corporate Governance on Corporate Cash Holdings: An empirical study of firms in manufacturing industry of Pakistan. International Journal of Innovation and Applied Studies, 7(4), 1371.

Bernanke, B. S., \& Gertler, M. (1995). Inside the black box: the credit channel of monetary policy transmission: National bureau of economic research.

Bofah, K. (2003). The Impact of Tax on Investment and Business Decisions.

Chemingui, M. A., \& Roe, T. (2008). Petroleum revenues in Gulf Cooperation Council, countries and their labor market paradox. Journal of Policy Modeling, 30(3), 491-503.

Devereux, M. P., \& Maffini, G. (2007). The impact of taxation on the location of capital, firms and profit: A survey of empirical evidence: Oxford University Centre for Business Taxation Working Paper Series.

Faccio, M., \& Xu, J. (2015). Taxes and capital structure. Journal of Financial and Quantitative Analysis, $50(3), 277-300$.

Gale, W. G., \& Samwick, A. A. (2014). Effects of income tax changes on economic growth. Available at SSRN 2494468.

Hakim, T. A., \& Bujang, I. (2012). The Impact and Consequences of Tax Revenues' Components on Economic Indicators: Evidence from Panel Groups Data: INTECH Open Access Publisher.

Hartman, D. G. (1985). Tax policy and foreign direct investment. Journal of Public economics, 26(1), 107121.

Javed, M. A., \& Basheer, M. F. (2017). Impact of external factors on bank profitability. EPRA International Journal of Research and Development, 2(5), 1-11.

Johannesen, N. (2014). Tax evasion and Swiss bank deposits. Journal of Public economics, 111, 46-62.

Johansson, Å., Heady, C., Arnold, J., Brys, B., \& Vartia, L. (2008). Taxation and economic growth.

McBride, W. (2012). What is the Evidence on Taxes and Growth? Tax Foundation, 207.

Nguyen, H. T. T., Nguyen, M. H., \& Goenka, A. (2013). How does FDI affect corporate tax revenue of the host country? Document De Recherche Epee, Centre D'etudes Des Politiques Economiques De L'universite D'evry, Retrieved August, 10(2014), 13-03.

Noeth, B. J., \& Sengupta, R. (2012). Global European banks and the financial crisis. Federal Reserve Bank of St. Louis Review, 94(November/December 2012).

Plosser, C. I. (1992). The search for growth: Policies.

Reinhart, C. M., \& Rogoff, K. S. (2009). This time is different: Eight centuries of financial folly. princeton university press.

Schepens, G. (2016). Taxes and bank capital structure. Journal of Financial Economics, 120(3), 585-600.

Stoilova, D., \& Patonov, N. (2013). An empirical evidence for the impact of taxation on economy growth in the European Union. Tourism \& Management Studies, 1031-1039.

Yi, F., \& Suyono, E. (2014). The Relationship between Tax Revenue and Economic Growth of Hebei Province Based on The Tax Multiplier Effect. Global Economy and Finance Journal, 7(2).

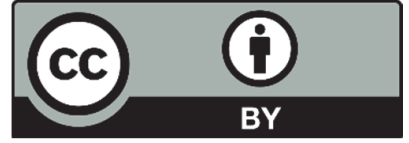

(C) 2019 by the authors; licensee Growing Science, Canada. This is an open access article distributed under the terms and conditions of the Creative Commons Attribution (CC-BY) license (http://creativecommons.org/licenses/by/4.0/). 